\title{
The Anatomy of Respiratory Organ of Climbing Perch (Anabas testudineus)
}

\author{
Erica Nuralam*, Muhammad Ja'far Luthfi \\ Biology Education Department, Faculty of Science and Technology, UIN Sunan Kalijaga \\ Jl. Marsda Adisucipto No. 1 Yogyakarta 55281, Indonesia. Tel. +62-274-540-971, Fax. +62-274-519739 \\ "Email: ericanuralam95@gmail.com
}

\begin{abstract}
The study aims to find out about the anatomical and histological structure of gill organ and labyrinth in Anabas Testudineus. The organ used is gill and labyrinth of climbing perch. The histological observation is done by making the histological preparation applied to a Hematoxylin-Eosin staining. The result of this study shows that the anatomical gill of climbing perch consists of the gill filaments and gill rakers attaching to the gill arch and the cartilage fold which are shaped like a rose. Then, the histological observation of climbing perch gill consists of the gill filament and gill arch. The gill arch is composed of gill rakers, mucosal epithelium, adipose tissue, basal membrane, mucous cell, submucosa, artery, and bone tissue. The gill filament consists of primary and secondary lamella. Primary lamella is composed of cartilage coated by perichondrium, central venous sinus, chloride cell, while secondary lamella is composed of squamous epithelium cell, mucous cell, pillar cell, and erythrocyte. Labyrinth is made up of adipose tissue, elastic cartilage, perichondrium, epithelium, blood vessel, connective tissue, and mucous cell.
\end{abstract}

Keywords: Anatomy, Climbing perch, Gill, Histology, Labyrinth

\section{INTRODUCTION}

Climbing perch (Anabas testudineus) is one of the freshwater fish mostly found in swamps, rice fields, small rivers, ditches, and ponds which get flooded water or associated with open waterways. According to Olson (1981), climbing perch is a freshwater fish which has the ability of air-breathing with supporting organ of air-breathing organ (ABO). This group of air-breathing fish can breathe in the air which has evolved with airbreathing organ $(\mathrm{ABO})$ to absorb oxygen in the air from above the water surface (Taylor et al., 2010).

Climbing perch has breathing aid (breathing organ) like cork and catfish. This fish also has a labyrinth organ so that it can take oxygen directly from the air. Labyrinth has an enormous function when the fish gets drought and must move to another place with sufficient water content (Affandi, 2002). The labyrinth is an additional breathing aid in the form of a labyrinth fold and a derivative of the first-gill slit. This organ is located above a cavity behind the gill and the air will be accommodated in the labyrinth cavity when it will appear on the water surface (Yudha, 2013).

The histological structure of fish gills is composed by several primary lamellas. One primary lamella consists of several secondary lamellas. The length and width of the secondary lamellas are almost same. Fish's respiratory cells consist of only two or three layers of epithelium located in the basal membrane. These cells are covered by a thin and semipermeable epidermal membrane (Sukarni et al., 2012).

The study of the anatomical and histological respiration of climbing perch in tropical countries such as Indonesia is still very limited. How to adapt to the ability of air-breathing which is different from other aquatic fish is one of the uniqueness of climbing perch. Therefore, the basic information about its structure of the respiratory organs is very necessary. Based on this explanation, it is necessary to study about the anatomical and histological respiratory organs in climbing perch.

\section{MATERIALS AND METHODS}

This study uses gill samples and labyrinths of climbing perch. The study is started by section the climbing perch to be taken and observed for gill and labyrinth samples. Then the samples are made into histological preparation with paraffin method and HematoxylinEosin (HE) staining. The observation of preparations uses a light microscope connected to an optilab camera.

\section{RESULTS AND DISCUSSION}

\section{The Anatomy of Respiratory Organ of Climbing Perch}

Based on the macroscopic observation, the respiratory organ of climbing perch is composed of gills and labyrinths. The anatomy of its respiratory organ is in (Figure 1). Climbing perch is a true bony fish with one character having operculum as a gill cover. Climbing perch gills are located on the lower head and red which indicate that they contain many capillary blood vessels. Climbing perch has four pairs of gill slits on each side arranged of gill raker, gill arch, and filament with a pair of lamella. The climbing perch labyrinth has a shape like a rose petal located above the gills which are an extension of the first gill cavity. Its labyrinth is red 
because it has capillary blood vessels capable of taking oxygen directly from the air. This has the same function of labyrinth to absorb oxygen reserves when the fish appears on the surface of the water, so that the fish can live in oxygen-poor water.

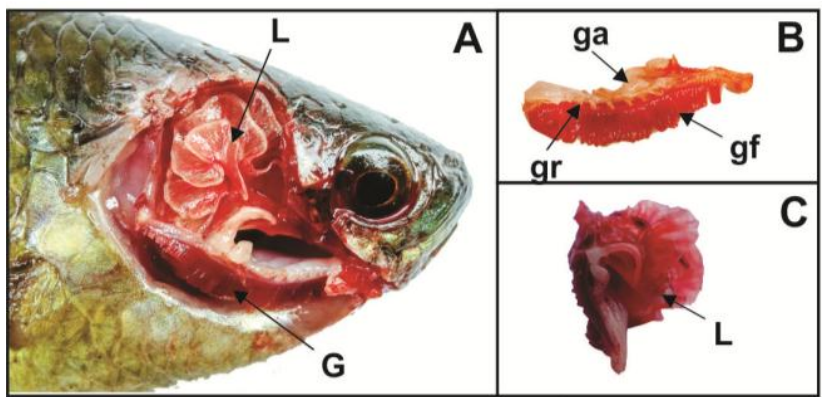

Figure 1. The anatomy of respiratory organ of climbing perch: A Labyrinth (L), Gill (G). B. Gill arch (ga), Gill rakers (gr), Gill filament (gf). C. Labyrinth (L).

\section{The Histology of Respiratory Organ of Climbing Perch}

The histological gill of climbing perch consists of gill filaments and gill arches. Gill arches are composed of gill raker, mucosal epithelium, adipose tissue, basal membrane, mucus, submucosal cell, artery, and bone tissue. Gill filament consists of primary and secondary lamella. The primary lamella is composed of cartilage covered by perichondrium, central venous sinus, and chloride cell, whereas secondary lamella is composed of squamous epithelium cell, mucous cell, pillar cell and erythrocyte. Labyrinth is made up of adipose tissue, elastic cartilage, perichondrium, epithelium, blood vessel, connective tissue, and mucous cell.

\section{The Histology of Gill}

Histologically, the gill has a thin epithelial layer. According to Nabib and Pasaribu (1989), histologically the epithelial surface area of the gill resembles the surface area of the skin even in most fish species having a wider epithelial surface than the epithelial surface of the skin, so that the gill has an important role in the homeostatic process and very useful for efficiency gas exchange, namely oxygen absorption and carbon dioxide release.

The gill filament consists of primary and secondary lamella. The filament has many blood capillaries so that oxygen can diffuse in and carbon dioxide diffuses out. Along the primary lamella, there are many branches which are in the form of smooth slits called secondary lamella and located perpendicular to the primary lamella. The secondary lamella structure functions for gas exchange (Figure 3). Erlangga (2007) states that the tissue structure of gill filament is composed of a thin epithelium on the outside, base membrane, and pole cells as a buffer on the inside.

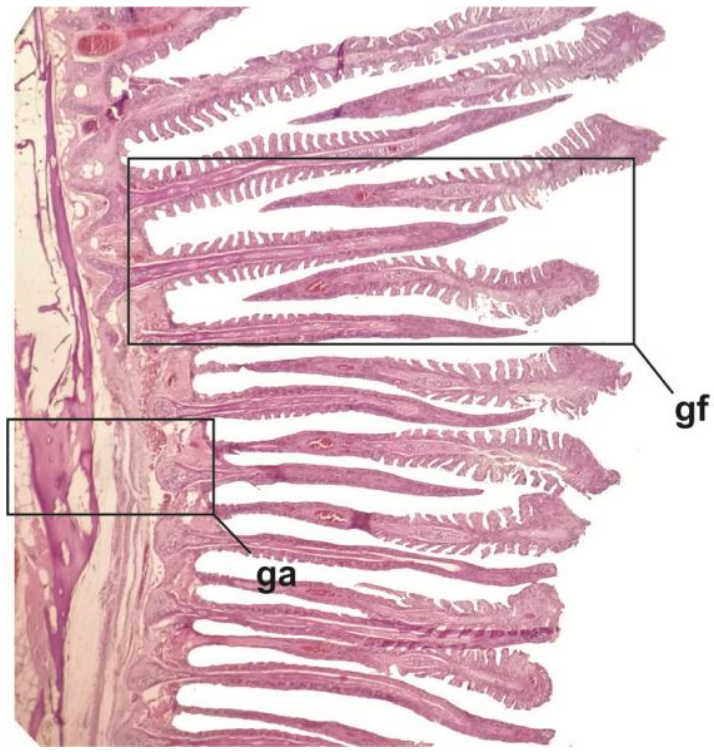

Figure 2. The histology of respiratory system of climbing perch: Gill filament (gf), Gill arch (ga). HE (Enlargement 4x).

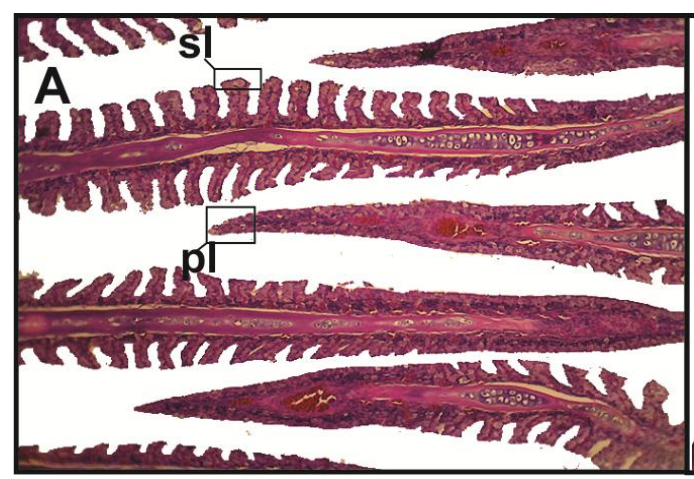

Figure 3. The histology of climbing perch filament: A. Primary lamella (pl), Secondary lamella (sl). HE (Enlargement 10x).

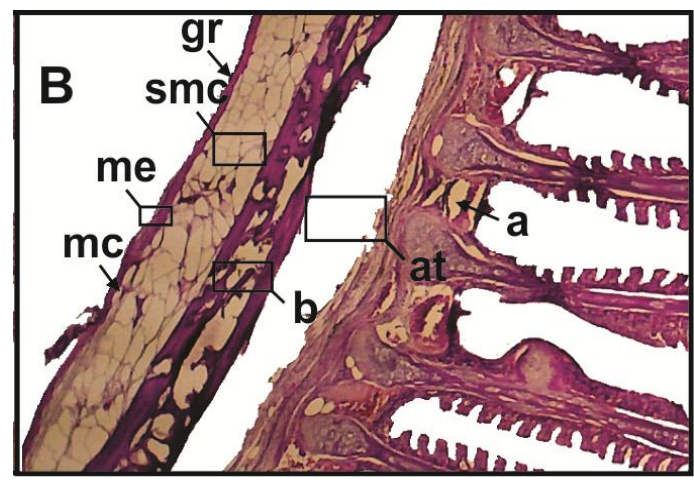

Figure 4. The histology of gill arch of climbing perch: B. Artery (a), Gill rakers (gr), Mucosal epithelium (me), Adipose tissue (at), Mucous cel (mc), Submucosal cell (smc), Bone (b). HE (Enlargement 10x).

The gill arch is composed of cartilage as the attachment of the primary lamella. The gill arch contains the afferent brachial artery of the ventral aorta and the brachial efferent aorta artery of the dorsal aorta. Histologically, the gill arch consists of gill raker, basal 
membrane, submucosal, bone, adipose tissue, artery, mucosal epithelium, and mucus cell in (Figure 4).

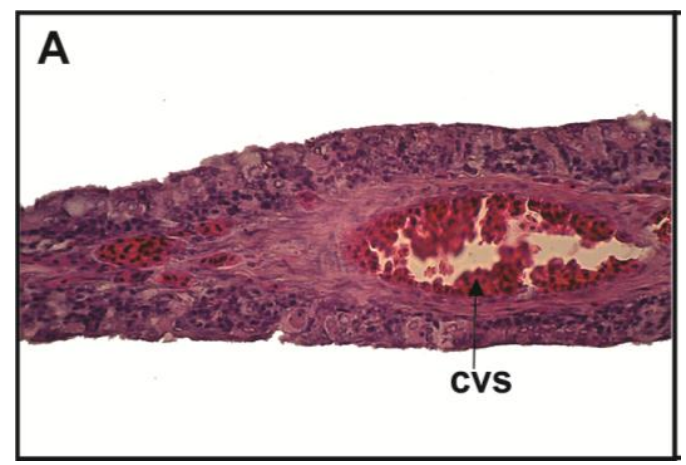

Figure 5. The histology of primary lamella in the tip. A. Central venous sinus (cvs). HE (Enlargement 40x).

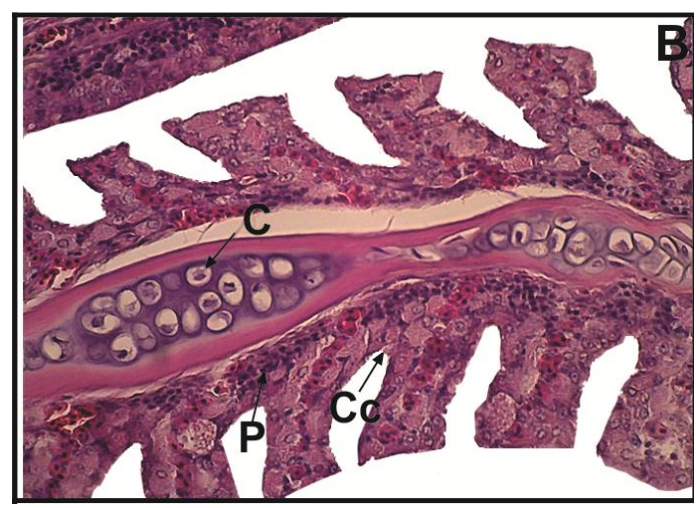

Figure 6. The Histology of primary lamella in the middle. B. Cartilage (c), Perichondrium (p), Chloride cell (cc). HE (Enlargement 40x).

The middle part of the primary lamella is the central venous sinus in the form of a large channel along the primary lamella and containing erythrocytes in it (Figure 5). Histologically, the primary lamella consists of cartilage covered by perichondrium, central venous sinus, and chloride cell (Figure 6).

The secondary lamella is a transverse sheet. The outer wall of the secondary lamella consists of a layer of squamous epithelium cell, the epithelium sheath which is wrapped by the medial vascular layer and a blood capillary woven from the efferent brachial artery of the pillar cell. Secondary lamella consists of epithelial cells, pillar cells, mucosal glands, chloride cells, and blood vessels (Figure 7). In secondary lamella, there are pillar and mucus cell which are laid on the peripheral gill along the primary and secondary lamella oval. The color of pillar cells more concentrate and polyhedral. The pillar cell is arranged lined and wrapped by thin and semipermeable epidermal membranes, and there are spaces between the pillar cell called lacuna which connects to afferent and efferent arterial blood.

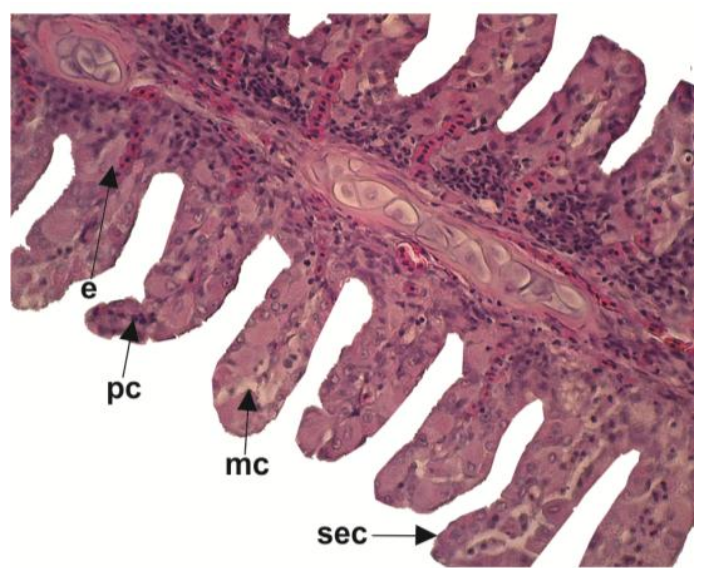

Figure 7. The histology of secondary lamella of climbing perch. Squamous epithelium cell (sec), Mucus cell (mc), Pillar cell (pc), Erythrocyte (e). HE (Enlargement 40x).

Gill is also equipped by a number of glands called the brachial gland which is gill epithelial cell that specializes. The gland is the mucosal gland and acidophilic gland (chloride cell), generally oval. Affandi and Tang (2002) say that chloride cell functions in the exchange of salt, the removal of salt in seawater fish, and the taking of salt in freshwater fish. Besides, mucus cell is single oval cell and produce mucus. Mucus is a glycoprotein which is alkaline or neutral and serves as protection, decreases friction, anti-pathogen, and helps the exchange of ion, gas, and water.

\section{The Histology of Labyrinth}

The labyrinth of climbing perch consists of elastic cartilage, epithelium, mucous cell, blood cell, adipose cell, and connective tissue. The labyrinth is an additional breathing aid in the fish in the form of fold of the respiratory epithelium. The fold is a modification of the surface epithelium and a type of microvilli namely microfilament functioning in the absorption of substances and expanding the cell surface. Some types of epithelium form a bulge to expand the surface area. It is consistent with the shape of the labyrinth in the form of irregular folds.

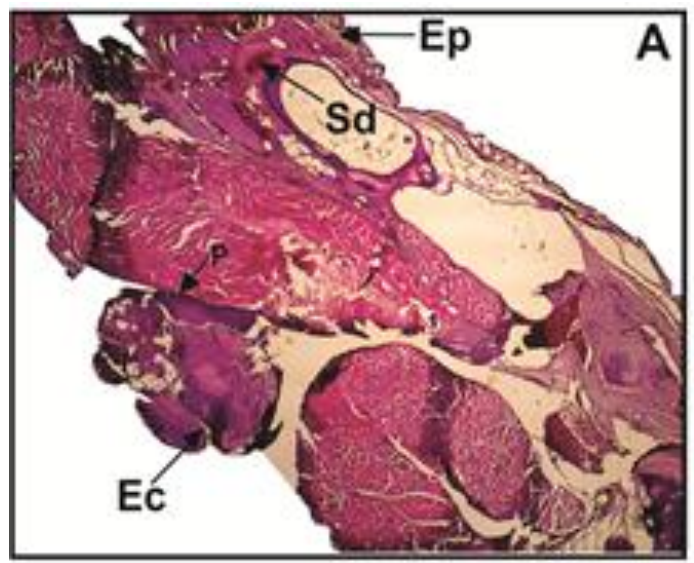

Figure 8. The histology of climbing perch labyrinth. (tre) Elastic cartilage, (p) Perichondrium, (ep) Epithelium. HE (Enlargement 4x). 


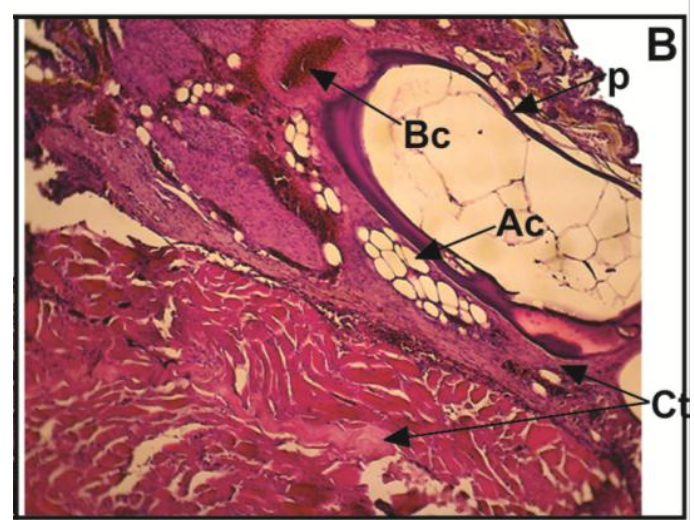

Figure 9. The histology of climbing perch labyrinth. (ac) Adipose cell, (bc) Blood cell, (p) Perichondrium, (ct) Connective tissue. HE (Enlargement 10x).

Epithelial cell has not only a role in oxygen exchange, but it also has a role in the blood filtering and diffusion processes which allows oxygen to pass through the blood. This process helps the movement of small blood vessel immune cell in the surrounding tissue. The elastic cartilage in the climbing perch labyrinth is covered by perichondrium and consists of cells called chondrocytes and a broad extracellular matrix consisting of fibers and basic substances. Chondrocytes synthesize and secrete the extracellular matrix and the cells themselves are in the cavity of the matrix called lacuna. Loose connective tissue is a tissue whose cells are sparse and half of the tissue is composed of a matrix located below the epithelial layer at the deepest part of the capillary blood vessel and cartilage structure. The connective tissue functions to provide a matrix and bind the tissues and cells. Besides, there are many blood vessels that are spread between the layers of epithelium and the connective tissue which spreads between the epithelium layer and cartilage tissue, allowing the spread of blood cells as a place for air exchange in the labyrinth.

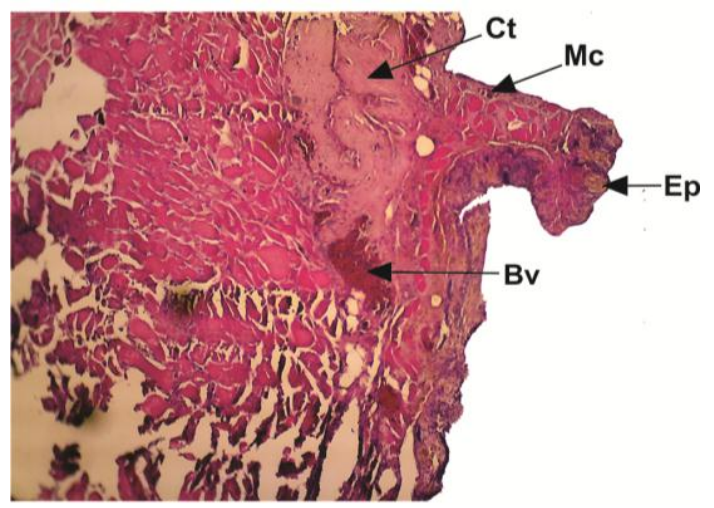

Figure 10. The histology of climbing perch labyrinth. (bv) Blood vessel, (mc) Mucus cell, (ct) Connective tissue, (ep) Epithelium. HE (Enlargement 10x).

\section{CONCLUSIONS}

The anatomy of climbing perch gill consists of gill filaments and gill rakers which are attached to the gill arch. Then the anatomy of the climbing perch labyrinth consists of cartilage folds shaped like rose petals. Besides, the histological observation of climbing perch gill consists of gill filaments and gill arches. Gill arches are composed of gill raker, mucosal epithelium, adipose tissue, basal membrane, mucous cell, submucosa, artery, and bone tissue. Gill filaments consist of primary and secondary lamella. Primary lamella is made up of cartilage covered by perichondrium, central venous sinus, and chloride cell, whereas secondary lamella is composed of squamous epithelium cell, mucous cell, pillar cell, erythrocyte dam. The labyrinth consists of adipose cell, elastic cartilage, perichondrium, epithelium, blood cell, connective tissue, and mucous cell.

\section{REFERENCES}

Affandi, R, dan Tang, U. 2002. Fisiologi Hewan Air. Riau: University Riau Press.

Erlangga, 2007. Efek pencemaran perairan sungai Kampar di provinsi Riau terhadap ikan Baung (Hemibagrus nemurus). Tesis. Bogor: Sekolah Pascasarjana Institut Pertanian Bogor.

Nabib R dan FH Pasaribu. 1989. Patologi dan Penyakit Ikan. Bogor: Departemen Pendidikan dan Kebudayaan.

Olson K R, J.S. D Munshi, T. K, Ghosh, J. Ojha. Gill microcirculation of the air-breathing climbing perch, Anabas testudineus (Bloch): Relationships with the accessory respiratory organs and systemic circulation. Am. J.Anat. 1986; 176:305320.

Sukarni, Maftuch dan H Nursyam. 2012. Kajian penggunaan ciprofloxacin terhadap histologi insang dan hati ikan Botia (Botia macracantus, bleeker) yang diinfeksi bakteri Aeromonas hydrophila. J. Exp. Life Sci.2(1)

Taylor, E.W., C.A.C. Leite, D.J. McKenzie \& T. Wang. 2010. Control of respiration in fish, amphibians and reptiles. Brazilian Journal of Medical and Biological Research (2010) 43: 409424.

Yudha, R. 2013. Perkembangan bentuk dan struktur histologis labirin dan modifikasi sirip ventral (filamen) ikan gurami (Osphronemus gouramy lacepede). Tesis. Yogyakarta: Jurusan Biologi Universitas Gajah Mada. 